\title{
PENGARUH SISTEM OLAH TANAH DAN APLIKASI HERBISIDA TERHADAP RESPIRASI TANAH PADA LAHAN PERTANAMAN JAGUNG (Zea mays) MUSIM TANAM KE TIGA
}

\author{
Endah Pangestuning, Sri Yusnaini, Ainin Niswati \& Henrie Buchori \\ Jurusan Agroteknologi Fakultas Pertanian Universitas Lampung \\ Jl. Professor Doktor Sumantri Brojonegoro No. 1, Bandar Lampung, Lampung 35145 \\ E-mail: epangestuning@yahoo.com
}

\begin{abstract}
ABSTRAK
Respirasi tanah merupakan salah satu indikator dari aktivitas biologi seperti mikroba, akar atau kehidupan lain di dalam tanah, dan aktivitas ini sangat penting untuk ekosistem di dalam tanah. Penetapan respirasi tanah berdasarkan penetapan jumlah $\mathrm{CO}_{2}$ yang dihasilkan oleh mikroorganisme tanah dan jumlah $\mathrm{O}_{2}$ yang digunakan oleh mikroorganisme tanah. Respirasi tanah sudah banyak dikaji dalam kaitannya dengan kesehatan tanah dan sekuestrasi karbon. Penelitian dilakasanakan di Laboratorium Lapangan Terpadu Fakultas Pertanian Universitas Lampung sejak Mei 2015 sampai Agustus 2015. Pengambilan sampel dilakukan sebanyak 3 kali. Penelitian ini dirancangan dalam Rancangan Acak Kelompok (RAK) secara faktorial yang terdiri dari dua faktor yaitu sistem olah tanah dan aplikasi herbisida dengan 4 kali ulangan. Sistem olah tanah terdiri dari olah tanah maksimun $\left(\mathrm{T}_{1}\right)$ dan olah tanah minimum $\left(\mathrm{T}_{0}\right)$. Sedangkan aplikasi herbisida yaitu terdiri dari aplikasi herbisida $\left(\mathrm{H}_{1}\right)$ dan non aplikasi herbisida $\left(\mathrm{H}_{\mathrm{o}}\right)$. Data yang diperoleh dianalisis dengan sidik ragam pada taraf $5 \%$ yang terlebih dahulu diuji homogenitas ragamnya dengan menggunakan Uji Bartlett dan adivitasnya diuji dengan Uji Tukey. Rata-rata nilai tengah dari data diuji dengan uji BNT pada taraf 1\% dan 5\%. Hubungan antara kelembaban, suhu tanah, C-organik, N, P dan K dengan respirasi tanah diuji dengan uji korelasi. Hasil penelitian menunjukan bahwa perlakuan sistem olah tanah pada 1 bulan setelah tanam berpengaruh terhadap respirasi tanah tetapi tidak pada 2 dan 3 bulan setelah tanam, perlakuan aplikasi herbisida berpengaruh terhadap respirasi tanah pada pengamatan 2 bulan setelah tanam tetapi tidak pada 1 dan 3 bulan setelah tanam, tetapi terdapat interaksi antara sistem olah tanah dan aplikasi herbisida pada respirasi tanah dipengamatan 1 dan 2 BST, tetapi tidak pada 3 bulan setelah tanam pada pertanaman jagung (Zea mays). Perlakuan sistem olah tanah maksimum dengan herbisida menunjukkan respirasi paling tinggi dibandingkan dengan perlakuan lainnya.
\end{abstract}

Kata kunci: Herbisida, Respirasi tanah, Sistem olah tanah.

\section{PENDAHULUAN}

Pengolahan tanah sudah lazim dilakukan oleh petani dalam usaha untuk meningkatkan pertumbuhan dan produksi tanaman. Pengolahan tanah adalah kegiatan manipulasi mekanik terhadap tanah untuk menciptakan keadaan tanah yang baik bagi pertumbuhan tanaman. Berbagai sistem olah tanah akan berpengaruh terhadap kadar bahan organik tanah dan laju respirasi tanah. Handayani (1999) menyatakan bahwa sistem olah tanah dapat mempengaruhi kuantitas $\mathrm{CO}_{2}$ dalam tanah. Sistem olah tanah maksimum membuat struktur tanah menjadi gembur, aerasi baik sehingga dapat meningkatkan aktivitas mikroorganisme dan laju respirasi tanah, sehingga $\mathrm{CO}_{2}$ menjadi tersedia.

Terdapat sistem olah tanah konservasi (OTK) yang di dalamnya mencakup olah tanah minimum (OTM) yang dapat dilaksanakan tanpa merusak kelestarian lingkungan (LIPTAN, 1994). Olah tanah minimum (OTM) dilakukan dengan mengolah tanah seperlunya saja. Apabila pertumbuhan gulma tidak begitu banyak, pengendaliannya dilakukan secara manual (dibesik) sekaligus membersihkan gulmanya. Tetapi jika kurang berhasil, pengendalian gulma dapat dilakukan dengan menggunakan herbisida layak lingkungan (Utomo dkk., 2012).

Menurut Utomo (2006), pengolahan tanah secara terus - menerus juga dapat menimbulkan dampak negatif yaitu menyebabkan terjadinya degradasi tanah yang diikuti dengan kerusakan struktur tanah, peningkatan terjadinya erosi tanah, dan penurunan kadar bahan organik tanah yang berpengaruh juga terhadap keberadaan biota tanah. Salah satu sistem pengolahan tanah yang dianggap baik untuk keberlanjutan kesuburan tanah adalah sistem olah tanah konservasi atau sistem olah tanah minimum.

Dalam olah tanah konservasi, pengguna herbisida juga sering dilakukan untuk tanaman. Penggunaan 
herbisida tidak dapat dipisahkan untuk penyiapan lahan pada sistem TOT. Gulma yang tumbuh di atas permukaan tanah yang biasanya dikendalikan dengan cangkul, traktor atau alat mekanisasi lainnya digantikan dengan penyemprotan herbisida untuk mematikan gulma maupun sisa tanaman yang masih hidup, yang selanjutnya dimanfaatkan sebagai mulsa dan bahan organik (Sebayang dkk., 2002). Hal ini dimaksudkan untuk mengendalikan gulma yang tumbuh sehingga tanah tidak terganggu secara fisik.

Pengendalian gulma secara manual akan menjadi tidak efisien bila lahan pertanaman cukup luas, maka penggunaan herbisida diharapkan dapat mengurangi tenaga kerja dan waktu yang relatif singkat. Adapun cara kerja dari herbisida, yang langsung masuk ke tanah akan mematikan akar gulma. Oleh karena itu herbisida mampu menekan pertumbuhan gulma (Listyobudi, 2011).

Salah satu indikator dari aktivitas biologi tanah adalah respirasi tanah. Respirasi tanah adalah proses evolusi $\mathrm{CO}_{2}$ dari tanah ke atmosfer, terutama dihasilkan oleh mikro-organisme tanah dan akar tanaman. Hal ini dipengaruhi tidak hanya oleh faktor biologis (vegetasi, mikro-organisme) dan faktor lingkungan (antara lain suhu, kelembaban, $\mathrm{pH}$ ), tetapi juga lebih kuat oleh faktor buatan manusia. Fang dkk.,(1998) respirasi tanah menggambarkan aktivitas mikroorganisme tanah.

Jagung merupakan salah satu komoditas pangan penting di Indonesia setelah padi. Jagung memiliki peranan strategis dan bernilai ekonomis serta mempunyai peluang untuk dikembangkan, mengingat komoditas ini mempunyai fungsi yang multiguna, selain untuk pangan juga sebagai pakan dan industri. Dewasa ini penggunaan jagung untuk kebutuhan bahan baku industri mulai berkembang, seperti pembuatan minyak jagung, tepung, pati, serta industri kimia (etil alkohol aseton, asam laktat, asam sitrat dan gliserol) (Purwono dan Hartono, 2005). Oleh karena itu, penerapan sistem olah tanah dan aplikasi herbisida dilakukan pada pertanaman jagung.

Tujuan penelitian ini adalah (1) Mempelajari pengaruh sistem olah tanah terhadap respirasi tanah pada pertanaman jagung musim ke -3.(2) Mempelajari pengaruh aplikasi herbisida terhadap respirasi tanah pada pertanaman jagung musim ke -3.(3) Mempelajari pengaruh interaksi antara sistem olah tanah dan aplikasi herbisida terhadap respirasi tanah pada pertanaman jagung musim ke-3.

\section{BAHAN DAN METODE}

Penelitian ini dilaksanakan pada bulan Mei 2015 sampai dengan Agustus 2015 pada lahan percobaan di
Laboratorium Lapang Terpadu, Fakultas Pertanian, Universitas Lampung. Analisis sampel tanah dilakukan di Laboratorium Ilmu Tanah, Fakultas Pertanian, Universitas Lampung.

Alat yang digunakan dalam penelitian ini yaitu cangkul, sabit, botol film, timbangan, plastik, erlenmeyer, gelas ukur, pipet tetes, selotipe, kertas label, buret, corong dan penyungkup (toples). Sedangkan bahan yang digunakan dalam penelitian ini yaitu sampel tanah, $\mathrm{KOH}$ $0,1 \mathrm{~N}$, penolptalin, aquades, $\mathrm{HCl} 0,1 \mathrm{~N}$, metil orange dan aquades. Alat yang digunakan dalam penelitian ini yaitu cangkul, sabit, botol film, timbangan, plastik, erlenmeyer, gelas ukur, pipet tetes, selotipe, kertas label, buret, corong dan penyungkup (toples). Sedangkan bahan yang digunakan dalam penelitian ini yaitu sampel tanah, $\mathrm{KOH}$ $0,1 \mathrm{~N}$, penolptalin, aquades, $\mathrm{HCl} 0,1 \mathrm{~N}$, metil orange dan aquades.

Rancangan yang digunakan dalam penelitian ini adalah Rancangan Acak Kelompok (RAK) yang disusun secara faktorial yang terdiri dari dua faktor yaitu sistem olah tanah dan aplikasi herbisida. Sistem olah tanah terdiri dari olah tanah minimum $\left(\mathrm{T}_{0}\right)$ dan olah tanah maksimum $\left(\mathrm{T}_{1}\right)$. Sedangkan aplikasi herbisida terdiri dari non aplikasi herbisida $\left(\mathrm{H}_{0}\right)$ dan aplikasi herbisida $\left(\mathrm{H}_{1}\right)$. Dengan demikian terbentuk empat kombinasi perlakuan yaitu:

$\mathrm{T}_{0} \mathrm{H}_{0}=$ olah tanah minimum + non aplikasi herbisida $\mathrm{T}_{0} \mathrm{H}_{1}=$ olah tanah minimum + aplikasi herbisida $\mathrm{T}_{1} \mathrm{H}_{0}=$ olah tanah maksimum + non aplikasi herbisida $\mathrm{T}_{1} \mathrm{H}_{1}=$ olah tanah maksimum + aplikasi herbisida

Setiap perlakuan diulang sebanyak empat kali, sehingga diperoleh 16 petak percobaan. Data yang diperoleh dianalisis dengan sidik ragam pada taraf $1 \%$ dan 5\% yang terlebih dahulu diuji homogenitas ragamnya dengan menggunakan Uji Bartlett dan adivitasnya diuji dengan Uji Tukey. Rata-rata nilai tengah dari data diuji dengan uji BNT pada taraf $1 \%$ dan 5\%. Hubungan antara kelembaban, suhu tanah, C-organik, N, P dan K dengan respirasi tanah diuji dengan uji korelasi.

Pengukuran Respirai Tanah. Pengukuran respirasi tanah langsung dilakukan di lapangan, dengan mengambil sampel sebanyak 2 kali. Pengambilan sampel dilakukan pada pagi dan sore hari. Pengambilan sampel respirasi tanah dilakukan diantara baris tanaman jagung. Pengukuran respirasi tanah dilakukan dengan menutup permukaan tanah menggunakan toples yang di dalamnya telah diberikan botol film yang berisi $10 \mathrm{ml}$ $\mathrm{KOH} \mathrm{0,1} \mathrm{N.} \mathrm{Agar} \mathrm{tidak} \mathrm{terjadi} \mathrm{kebocoran,} \mathrm{toples}$ dibenamkan ke dalam tanah $2-3 \mathrm{~cm}$. Pengukuran ini dilakukan selama 2 jam. Pengukuran respirasi tanah dilakukan dengan meletakkan 2 buah toples pada setiap petak percobaan. Setelah pengukuran di lapangan 
selesai, $\mathrm{KOH}$ hasil pengukuran dititrasi di laboratorium untuk menentukan kuantitas $\mathrm{C}-\mathrm{CO}_{2}$ yang dihasilkan.

Analisis Laboratorium. Sampel $\mathrm{KOH}$ yang sudah berikatan dengan $\mathrm{CO}_{2}$ dari lapang kemudian dianalisis di laboratorium. $10 \mathrm{ml} \mathrm{KOH}$ tersebut dimasukkan ke dalam tabung Erlenmeyer dan ditetesi dengan 2 tetes penolptalin ( $\mathrm{pp}$ ) dan menimbulkan warna pink, lalu dititrasi dengan $0,1 \mathrm{NHCl}$ hingga warna merah hilang. Volume HCL yang digunakan untuk titrasi tersebut kemudian dicatat. Lalu pada larutan tadi di tambah 2 tetes metyl orange, dan di titrasi kembali dengan $\mathrm{HCl}$ sampai warna kuning berubah menjadi pink. Jumlah $\mathrm{HCl}$ yang digunakan pada tahap kedua ini berhubungan langsung dengan jumlah $\mathrm{CO}_{2}$ yang difiksasi. Demikian juga dengan KOH blanko dilakukan lagi dengan prosedur yang sama dengan menggunakan sampel. Satu petak percobaan mewakili KOH sampel dan $\mathrm{KOH}$ blanko , maka terdapat 32 jumlah sampel $\mathrm{KOH}$ pada pagi hari dan $32 \mathrm{KOH}$ pada sore hari. Pada kontrol juga dilakukan hal yang sama. Jumlah $\mathrm{HCl}$ yang digunakan pada tahap kedua ini berhubungan langsung dengan jumlah $\mathrm{CO}_{2}$ yang difiksasi. Demikian juga dengan $\mathrm{KOH}$ dari sampel blanko dilakukan prosedur yang sama dengan $\mathrm{KOH}$ sampel. Pengamatan respirasi dilakukan pada pagi dan sore hari.

Reaksi kimia yang terjadi selama proses titrasi $\mathrm{CO}_{2}$ dan dilanjutkan dengan titrasi menggunakan $\mathrm{HCl}$ adalah sebagai berikut :

1. Reaksi pengikatan $\mathrm{CO}_{2}$

$$
2 \mathrm{KOH}+\mathrm{CO}_{2} \quad \mathrm{~K}_{2} \mathrm{CO} 3+\mathrm{H}_{2} \mathrm{O}
$$

2. Perubahan warna menjadi tidak bewarna (fenolftalein)

$$
\mathrm{K} 2 \mathrm{CO} 3+\mathrm{HCl} \quad \mathrm{KCl}+\mathrm{KHCO} 3
$$

3. Perubahan warna kuning menjadi merah muda (metal orange)

$$
\mathrm{KHCO} 3+\mathrm{HCl} \quad \mathrm{KCl}+\mathrm{H}_{2} \mathrm{O}+\mathrm{CO}_{2}
$$

Perhitungan Respirasi Tanah. Respirasi tanah dapat dihitung dengan menggunakan rumus sebagai berikut:

$$
\mathrm{C}-\mathrm{CO}_{2}=\frac{(\mathrm{a}-\mathrm{b}) \times \mathrm{t} \times 12}{\mathrm{~T} \times \pi \times \mathrm{r}^{2}}
$$

Keterangan :

$\mathrm{C}-\mathrm{CO}_{2}=\mathrm{mg} \mathrm{jam}^{-1} \mathrm{~m}^{-2}$

$\mathrm{a}=\mathrm{ml} \mathrm{HCl} \mathrm{untuk} \mathrm{sampel}$

$\mathrm{b}=\mathrm{ml} \mathrm{HCl} \mathrm{untuk} \mathrm{blanko}$

$\mathrm{t}=\operatorname{normalitas}(N) \mathrm{HCl}$

$\mathrm{T}=$ waktu $($ jam $)$

$\mathrm{r}=$ jari-jari tabung toples $(\mathrm{m})$

Variabel Pengamatan. Variabel pengamatan pada penelitian ini meliputi :
1. Respirasi Tanah (Metode modifikasi Verstraete, Anas, 1987)

2. Kadar air tanah $(\%)$

3. C-organik tanah (\%) (metode Walkley and Black) 4. Suhu Tanah $\left({ }^{\circ} \mathrm{C}\right)$

\section{HASIL DAN PEMBAHASAN}

Hasil analisis ragam menunjukkan pada 1 bulan setelah tanam (1BST) pengolahan tanah berpengaruh nyata terhadap respirasi tanah sedangkan herbisida tidak berpengaruh, tetapi terdapat pengaruh interaksi antara pengolahan tanah dan herbisida terhadap respirasi tanah. Pada 2 bulan setelah tanam (2BST) pengolahan tanah tidak berpengaruh nyata terhadap respirasi tanah sedangkan herbisida berpengaruh nyata dan terdapat interaksi antara tanah dan herbsida terhadap respirasi tanah. Pada 3 bulan setelah tanam (3BST) pengolahan tanah, herbisida, dan interaksi antara tanah dan herbisida tidak berpengaruh nyata terhadap respirasi tanah (Tabel $1)$.

Hakekatnya respirasi tanah adalah proses mikrobiologis, selain oleh perakaran tanaman. Bahan timbunan yang mengandung cukup kapur atau karbon juga potensial untuk teroksidasi dan melepaskan $\mathrm{CO}_{\text {. }}$. Dengan melihat perubahan bahan organik (serasah) menjadi bahan organik tanah, laju respirasi tanah dapat ditafsirkan secara maksimal (Setyawan dkk., 2011).

Hasil uji BNT (Tabel 2) menunjukkan bahwa pada perlakuan olah tanah minimum, respirasi tanah lebih tinggi pada perlakuan tanpa herbisida, tetapi pada olah tanah maksimum respirasi pada perlakuan herbisida lebih tinggi dari pada tanpa herbisida. Respirasi pada perlakuan tanpa herbisida tidak berbeda nyata antara olah tanah maksimum dengan olah tanah minimum, tetapi pada perlakuan herbisida olah tanah maksimum nyata lebih tinggi dari pada olah tanah minimum.

Tingginya laju respirasi tanah pada awal penelitian disebabkan karena masih adanya bahan organik yang cepat didekomposisi, akibatnya dari pengolahan tanah yang dilakukan pada awal pertanaman, semakin lama tanah akan menjadi padat sehingga $\mathrm{CO}_{2}$ yang keluar dari tanah pun semakin tipis. Bahan organik seperti gula dan protein merupakan senyawa yang cepat sekali terdekomposisi. Senyawa yang cepat sekali didekomposisi menyebabkan senyawa organik yang ada didalamnya akan cepat habis, sehingga laju respirasi tanah juga mengalami penurunan karena menurunnya aktivitas mikrooganisme di dalam tanah. Masih ada senyawa yang lambat terdekomposisi di dalam tanah seperti lignin, selulosa, hemi selulosa, dan lemak 
Tabel 1. Ringkasan analisis ragam pengaruh pengolahan tanah dan herbisida terhadap respirasi tanah $\mathrm{CO}_{2}-\mathrm{C}\left(\mathrm{mg} \mathrm{jam}^{-1} \mathrm{~m}^{-2}\right)$ pada 1,2 dan $3 \mathrm{BST}$.

\begin{tabular}{cccc}
\hline Perlakuan & 1BST & 2BST & 3BST \\
\hline & $\ldots \ldots \ldots$ & $\mathrm{CO}_{2}-\mathrm{C}\left(\mathrm{mg} \mathrm{jam}^{-1} \mathrm{~m}^{-2}\right) \ldots \ldots \ldots$ & \\
T0H0 & 31,2 & 29,25 & 20,48 \\
T0H1 & 16,09 & 23,4 & 17,55 \\
T1H0 & 28,27 & 13,65 & 19,99 \\
T1H1 & 42,9 & 39,97 & 23,89 \\
\hline Sumber keragaman & & F hitung dan signifikansi & \\
\hline T & $9,96^{*}$ & $0,02^{\text {tn }}$ & $1,32^{\text {tn }}$ \\
H & $0,00415^{\text {tn }}$ & $9,90^{*}$ & $0,04^{\text {tn }}$ \\
TxH & $15,44^{*}$ & $24,44^{*}$ & $1,79^{\text {tn }}$ \\
\hline
\end{tabular}

Keterangan: $\mathrm{tn}=$ tidak berbeda nyata pada taraf $5 \%, *=$ berbeda nyata pada taraf $5 \%$, $\mathrm{T}=$ Pengolahan tanah, $\mathrm{H}=$ herbisida, $\mathrm{TXH}=$ Interaksi antara pengolahan tanah dan herbisida.

Tabel 2. Pengaruh interaksi antara sistem olah tanah dan aplikasi herbisida terhadap respirasi tanah saat 1 BST pada pertanaman jagung (Zea mays)

\begin{tabular}{ccc}
\hline Perlakuan & Tanpa Herbisida & Herbisida \\
\hline & $\ldots \ldots . .\left(\mathrm{CO}_{2}-\mathrm{C}\left(\mathrm{mg} \mathrm{jam}^{-1} \mathrm{~m}^{-2}\right)\right)$ & $\ldots \ldots \ldots \ldots \ldots$ \\
Olah Tanah Minimum & $31,20 \mathrm{~b}$ & $16,09 \mathrm{a}$ \\
& $(\mathrm{A})$ & $(\mathrm{A})$ \\
Olah Tanah Maksimum & $28,28 \mathrm{a}$ & $42,90 \mathrm{~b}$ \\
BNT $(0,05)$ & (A) & (B) \\
\hline
\end{tabular}

Keterangan: Nilai tengah yang diikuti oleh huruf yang sama tidak berbeda berdasarkan uji beda nyata terkecil (BNT) pada taraf 5\%, huruf kecil dibaca horizontal huruf kapital dibaca vertikal

sehingga masih tersedianya senyawa organik penyedia energi untuk melanjutkan aktivitas mikrooranisme didalam tanah (Hakim dkk., 1986).

Pada pengamatan 2 BST interaksi antara sistem olah tanah dan aplikasi herbisida berpengaruh nyata terhadap respirasi tanah. Respirasi tanah pada perlakuan olah tanah minimum untuk perlakuan tanpa herbisida lebih tinggi dibandingkan dengan perlakuan herbisida. Hal ini disebabkan karena herbisida yang digunakan yaitu herbisida bersifat sistemik. Herbisida sistemik yaitu herbisida yang dialirkan atau ditranslokasikan pada titik tumbuh gulma nya, maka untuk perlakuan herbisida, respirasi tanah pada olah tanah minimum lebih rendah karena gulma nya diserang pada titik tumbuh. Respirasi tanah pada perlakuan olah tanah minimum lebih tinggi karena tidak menggunakan herbisida.

Hasil uji BNT (Tabel 3) menunjukkan bahwa pada perlakuan olah tanah minimum respirasi pada pemberian herbisida dan tanpa herbisida tidak berbeda tetapi pada olah tanah maksimum, respirasi tanah tertinggi $(39,97$

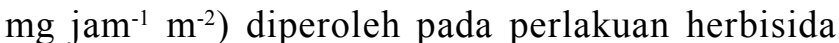
dibandingkan tanpa perlakuan herbisida (13,65 $\mathrm{mg} \mathrm{jam}^{-}$ ${ }^{1} \mathrm{~m}^{-2}$ ). Respirasi pada perlakuan tanpa herbisida nyata lebih tinggi pada olah tanah minimum dibandingkan olah tanah maksimum, tetapi pada perlakuan herbisida olah tanah maksimum nyata lebih tinggi dari pada olah tanah minimum.Keadaan ini diduga karena dengan adanya pengolahan tanah mengakibatkan ketersediaan bahan organik dan bagi mikroorganisme akan meningkat. Hal ini membuktikkan bahwa, aktivitas dan jumlah mikroorganisme di dalam tanah akan bertambah. Hal ini sesuai dengan penelitian yang dilakukan Kemas (2016) yang menunjukkan bahwa hasil perlakuan olah tanah maksimum dan aplikasi herbisida lebih tinggi dibandingkan dengan perlakuan yang lainnya dan juga terdapat interaksi antara perlakuan dengan respirasi tanah sehingga dapat meningkatkan hasil respirasi tanah. 
Bahan organik dijadikan sebagai salah satu tolak ukur untuk melihat kualitas, kesuburan atau produktivitas tanah. Pengurangan bahan organik tanah pada tanah mineral dapat menurunkan kualitas, kesuburan atau produktivitas tanah. Bahan organik tanah dapat berkurang melalui proses-proses pengambilan oleh tanaman, dekomposisi, dan erosi. Pengolahan tanah intensif dapat meningkatkan dekomposisi bahan organik sehingga mempercepat penurunan kandungan bahan organik tanah (Rachman dkk., 2013). Peranan bahan organik ada yang bersifat langsung terhadap tanaman, tetapi sebagian besar mempengaruhi tanaman melalui perubahan sifat dan ciri tanah.Seperti yang kita ketahui apabila dekomposisi bahan organik meningkat, maka akan meningkatkan aktivitas mikroorganisme serta dapat meningkatkan respirasi tanah. Semakin banyak $\mathrm{CO}_{2}$ yang dikeluarkan tanah, semakin tinggi aktivitas dan mikroorganisme, hal ini mengakibatkan semakin tinggi respirasi tanah.

Pada pengamatan 1,2 dan 3 BST pengolahan tanah, herbisida, dan interaksi antara pengolahan tanah dan herbisida tidak berpengaruh nyata terhadap suhu tanah. Menurut Hakim dkk. (1986), respirasi dipengaruhi oleh suhu, umumnya laju respirasi akan menjadi rendah pada suhu yang rendah pula dan meningkat pada suhu yang tinggi. Faktor penting lainnya yang mempengaruhi adalah kelembaban tanah. Keluaran $\mathrm{CO}_{2}$ tanah biasanya rendah dalam kondisi kering karena rendahnya akar dan aktivitas mikroorganisme dan meningkatkan kelembaban dengan tanah sampai batas tertentu (Linn dan Doran, 1984).

Hasil analisis ragam pada 1 bulan setelah tanam (1BST) pengolahan tanah sangat berpengaruh nyata terhadap respirasi tanah tetapi pada perlakuan herbisida dan interaksi antara pengolahan tanah dan herbisida tidak berpengaruh nyata terhadap respirasi tanah. Pada 2 bulan setelah tanam (2BST) pengolahan tanah, herbisida, dan interaksi antara tanah dan herbisida tidak berpengaruh nyata terhadap respirasi tanah. Pada 3 bulan setelah tanam (3BST) pengolahan tanah, herbisida, dan interaksi antara tanah dan herbisida tidak berpengaruh nyata terhadap respirasi tanah (Tabel 6).

Tabel 3. Pengaruh interaksi antara sistem olah tanah dan aplikasi herbisida terhadap respirasi tanah saat 2 BST pada pertanaman jagung (Zea mays)

\begin{tabular}{|c|c|c|}
\hline Perlakuan & Tanpa Herbisida & Herbisida \\
\hline & $\ldots \ldots \ldots\left(\mathrm{CO}_{2}-\mathrm{C}\left(\mathrm{mg} \mathrm{jam}^{-1} \mathrm{~m}^{-2}\right)\right)$ & ... \\
\hline Olah Tanah Minimum & $\begin{array}{c}29,25 \mathrm{a} \\
\text { (B) }\end{array}$ & $\begin{array}{l}23,40 \mathrm{a} \\
\text { (A) }\end{array}$ \\
\hline Olah Tanah Maksimum & $\begin{array}{c}13,65 \mathrm{a} \\
\text { (A) }\end{array}$ & $\begin{array}{l}39,97 \mathrm{~b} \\
\text { (B) }\end{array}$ \\
\hline $\operatorname{BNT}(0,05)$ & 10,41 & \\
\hline
\end{tabular}

Keterangan: Nilai tengah yang diikuti oleh huruf yang sama tidak berbeda berdasarkan uji beda nyata terkecil (BNT) pada taraf 5\%, huruf kecil dibaca horizontal huruf kapital dibaca vertikal

Tabel 6. Ringkasan analisis pengaruh pengolahan tanah dan herbisida terhadap Kadar Air Tanah (\%) pada 1, 2 dan 3 BST.

\begin{tabular}{|c|c|c|c|}
\hline & \multicolumn{3}{|c|}{ Kadar Air Tanah (\%) } \\
\hline & $1 \mathrm{BST}$ & 2BST & 3BST \\
\hline & \multicolumn{3}{|c|}{..$(\%) \ldots \ldots \ldots$} \\
\hline TOHO & 31,54 & 30,26 & 32,72 \\
\hline $\mathrm{T} 0 \mathrm{H} 1$ & 28,47 & 30,16 & 32,12 \\
\hline $\mathrm{T} 1 \mathrm{H} 0$ & 35,77 & 30,81 & 31,93 \\
\hline $\mathrm{T} 1 \mathrm{H} 1$ & 34,45 & 29,54 & 34,74 \\
\hline Sumber keragaman & \multicolumn{3}{|c|}{$\mathrm{F}$ hitung signifikan } \\
\hline $\mathrm{T}$ & $29,39^{* *}$ & $0,0019353^{\text {tn }}$ & $0,65^{\text {tn }}$ \\
\hline $\mathrm{H}$ & $5,43^{\text {tn }}$ & $0,74^{\mathrm{tn}}$ & $0,94^{\text {tn }}$ \\
\hline $\mathrm{TxH}$ & $0,86^{\mathrm{tn}}$ & $0,53^{\text {tn }}$ & $2,24^{\text {tn }}$ \\
\hline
\end{tabular}


Berdasarkan hasil uji korelasi antara respirasi tanah dengan C-organik tanah, kadar air tanah, dan suhu tanah menunjukkan bahwa respirasi tanah tidak adanya hubungan korelasi dengan kadar C-organik, kadar air tanah, dan suhu tanah, sehingga dinyatakan nilai respirasi tanah tidak dipengaruhi oleh kadar C-organik, kadar aiar tanah, dan juga suhu tanah.

\section{KESIMPULAN}

Perlakuan sistem olah tanah maksimum pada 1 bulan setelah tanam berpengaruh nyata terhadap respirasi tanah tetapi tidak pada 2 dan 3 bulan setelah tanam. Perlakuan aplikasi herbisida berpengaruh nyata terhadap respirasi tanah pada pengamatan 2 bulan setelah tanam tetapi tidak pada 1 dan 3 bulan setelah tanam. Terdapat interaksi antara sistem olah tanah dan aplikasi herbisida pada respirasi tanah dipengamatan 1 dan 2 BST, tetapi tidak pada 3 bulan setelah tanam pada pertanaman jagung (Zea mays). Perlakuan sistem olah tanah maksimum dengan herbisida menunjukkan respirasi paling tinggi dibandingkan dengan perlakuan lainnya.

\section{DAFTAR PUSTAKA}

Fang J, Zhao K, dan Liu S. 1998. Factors affecting soil respiration in reference with temperature's role in the global scale. Chinese Geographical Science 8(3): 246-255.

Hakim, N., Nyakpa, Y.M., Lubis, A.M., Nugroho, S.G., Saul, M.R., Dika, M.A., Ban-Hong, G., dan Bailey, H.H., 1986. Dasar-dasar Ilmu Tanah. Universitas Lampung. Jakarta. 488 hal.

Handayani, I.P. 1999. Kuantitas dan variasi nitrogentersedia pada tanah setelah penebangan hutan. Jurnal. Tanah Tropikal. 8:215-226..

Linn, D dan Doran, JW. 1984. Tillage Effects on Carbon Sequestration and Microbial Biomass in Reclaimed Farmland Soils of Southwestern Indiana. Soil Sci. Society. 48: 1267-1272.
LIPTAN. 1994. Lembar Informasi Pertanian (LIPTAN) BIP Irian Jaya No. 145/94. Balai Informasi Pertanian Irian Jaya, Jayapura. http:// www.pustaka -deptan.go.id/agritek/ ppua0138.pdf. (diakses 12 Januari 2016)

Listyobudi, V. R. 2011. Perlakuan herbisida pada sistem tanpa olah tanah terhadap pertumbuhan, hasil dan kualitas hasil tanaman jagung manis. Skripsi Fakultas Pertanian. Universitas Pembangunan Nasional "Veteran". Yogyakarta.

Purwono dan Hartono R.. 2005. Bertanam Jagung Unggul. Penebar Swadaya, Jakarta.

Rachman, L. M. Latifa, N dan Burida N. L.. 2013. Fisika Tanah Dasar. Departemen Ilmu Tanah dan Sumberdaya Lahan. Fakultas Pertanian. Institut Pertanian Bogor.

Sebayang, H. T., Tyasmoro S.Y. dan Pujiyanti D. E. 2002. Pengaruh waktu aplikasi herbisida glifosat dan pengendalian gulma terhadap pertumbuhan dan hasil tanaman jagung (zea mays) sistem tanpa olah tanah. Dalam: S. Hardiastuti, E. K., E. M. Nirmala, Lagiman, D. Kastono, S. Virgawati\& A. W. Rizain (eds.) Prosiding Seminar Nasional Budidaya Olah Tanah Konservasi. Yogyakarta, 30 Juli 2002. hal.1-15.

Setyawan D, Gilkes R, dan Tongway D. 2011. Nutrient cycling index in relation to organic matter and soil respiration of rehabilitated mine sites in Kelian, East Kalimantan. Journal Tropical Soil 11(3): 209-214.

Utomo, M. 2006. Olah Tanah Konservasi. Hand Out Pengelolaan Lahan Kering Berkelanjutan. Universitas Lampung, Bandar Lampung. $25 \mathrm{hlm}$.

Utomo, M., H. Buchari, dan Banuwa ,I. S. 2012. Olah Tanah Konservasi Teknologi Mitigasi Gas Rumah Kaca Pertanian Tanaman Pangan. Penerbit Universitas Lampung. $94 \mathrm{hlm}$. 